\title{
ПЕРСПЕКТИВЫ РАЗВИТИЯ ИНФОГРАФИКИ В ОБРАЗОВАТЕЛЬНОМ ПРОЦЕССЕ
}

\section{THE PERSPECTIVES OF INFORGRAPHIC DEVELOPMENT IN EDUCATIONAL PROCESS}

\section{N. Yakusheva G. Molodchikova}

Summary: The article deals with the main perspectives in the development of a new visual type of communication- inforgraphics as an instrument for transferring the information to the reader and user, to students and teachers in a laconic and the most accessible form.

In the process of education the cognitive level of scientific knowledge mostly depends on the accessibility of perception and understanding, teacher's explanation of the material. Inforgraphics, undoubtedly, can be effectively used in a foreign language teaching.

Keywords: inforgraphics, presentation of visual information, visual communication, infor-communicative aid, art method of visual information.
Якушева Нина Игнатьевна,

К.n.н., доцент, Брянский государственный университет имени академика И.Г. Петровского

n.i.yakusheva@yandex.ru

Молодчикова Галина Ивановна

Преподаватель, Брянский филиал Российского экономического университете имени Г.В. Плеханова galinamol2012@yandex.ru

Аннотация: В статье представлены основные перспективы развития нового вида визуальной коммуникации - инфографики как инструмента преподнесения информации читателю и пользователю, ученику и студенту в более лаконичной и доступной форме.

В процессе обучения уровень усвоения научного знания зависит от доступности восприятия, понимания, объяснения материала учителем. Без сомнения, инфографика может быть эффективно использована и на уроках иностранного языка.

Ключевые слова: инфографика, визуальная подача информации, визуальная коммуникация, информационно-коммуникативное средство, метод художественной визуализации информации.

учения, а уровень усвоения научного знания зависит от доступности восприятия, понимания объяснения материала учителем.

Практика работы в школе показывает, что уровень мотивации и интеллектуального развития у учащихся резко снизился. Это связано с тем, что освоение различных областей знания требует значительных усилий, терпения, когнитивных способностей. При этом большинство учащихся не представляют себе, как изучаемый материал может быть использован в практической деятельности.

Решению этой проблемы способствуют компьютерные технологии, интернет, СМИ, которые формируют новый способ восприятия информации, где визуальным образам отводится главное место.

Инфографика совмещает логику построения, яркость образов, объёмность информации и рассматривается как новое средство визуализации учебного знания.

Инфографике пока целенаправленно не учат в школе, однако мир не стоит на месте, это касается и образования. Сейчас в российских школах активно внедряют элементы современных информационных технологий, которые постоянно повышаются в своем качестве. 
Целью данной публикации является:

- Рассмотреть инфографику как элемент визуальной коммуникации;

- Перечислить виды инфографики;

- Рассмотреть инфографику как способ усвоения материала на уроках иностранного языка в старшей школе и вузе;

- Рассмотреть перспективы развития инфографики в образовательном процессе.

Роль визуальности в современной культуре и обществе является важным и неотъемлемым фактором - визуальное пространство не только информирует и развлекает, но и формирует определенные представления в различных системах отношений.

Таким образом, в разрезе визуального пространства и визуальной коммуникации следует уже говорить о таком явлении, как визуальная культура общества. В свою очередь, специфика визуальной культуры определяется ее семиотической природой и техническими возможностями средств ее реализации: высокая информационная емкость, легкость и убедительность чувств восприятия, доминирование репродуктивных возможностей над продуктивными, скорость и широта трансляции и тиражирования [2].

Стремительный темп жизни современного человека, недостаток времени, огромные информационные потоки, развитие технологий и инновационный прогресс - все это диктует новые требования и условия к подаче информации и успешному ее восприятию индивидом. На первый план уже выходит не текстовое сообщение, а зрительный образ, несущий заложенный смысл, логику, а в некоторых случаях уже и выводы.

Именно таким информационно-коммуникационным средством и является инфоргафика как составная часть обширного явления инфодизайна. Спектр применения инфографики широк - это журналистика и реклама, бизнес и статистика, научные труды и аналитика, технические инструкции и образование и т.д.

Для начала, следует разобраться с теоретической трактовкой этого термина. На данный момент, в силу недостаточности изучения этого явления, существует множество трактовок этого термина, но следует отметить наиболее точные.

Основная и традиционная формулировка термина «Инфографика» предстает следующим образом: «это графический способ подачи информации, данных и знаний, целью которого является быстро и четко преподносить сложную информацию» [4, с. 488].

Самуэль Веласко, как практикующий создатель Ин- фографики вот уже более 25 лет, трактует термин так: «это слово для меня всегда означало микс информации, дизайна и иллюстрации. Задача графики (дизайна и иллюстрации) в этом случае - выявлять и отображать то, для чего недостаточно слов» [1]. В соответствии с трактовкой испанского профессора Валеро Санчо, это «информационный элемент, выраженный при помощи изображения и типографических элементов, который позволяет понять или существенно облегчить понимание событий, действий или каких-либо важных аспектов и сопровождает или заменяет текстовую информацию» $[3$, c.15].

Эдвард Тафти - известный теоретик инфографики говорит о том, что «инфографика должна быть минималистичной, все несущественное и препятствующее восприятию информации должно быть опущено, а сами данные должны быть переданы максимально точно»» [5, с. 45].

Иной подход демонстрирует Найджел Холмс (он иллюстрировал редакционные колонки некоторых англоязычных печатных изданий) делающих ставку на выразительность и иллюстративность в инфографике, созданием привлекательных для читателя образов и развлечением.

Таким образом, инфографика представляет собой информационное сообщение, выраженное графическим языком с помощью комплексной системы графических изображений и текста, представленное максимально просто, лаконично и доступно.

Рассматривая линию становления инфографики как направления графического дизайна, можно проследить ее элементы и характерные черты в самых различных периодах развития человеческого общества. Так, например, отправной точкой можно считать наскальные рисунки в эпоху Первобытного общества, или система координат и амфорные событийные рисунки в эпоху Античности, иллюстрируемые научные труды средних веков и т.д.

Непосредственное же становление инфографики как комплексной визуально-информационной системы и нового жанра возникает в конце XX века на стыке журналистики, дизайна и статистики сравнительно недавно. Началом принято считать американское издание 1982 г. USA Today, где впервые была представлена систематизированная информация в виде поясняющих картинок с подписями, схемами, картами и диаграммами. Именно такая форма подачи материала стала иметь успех у читателя, а соответственно и у коммерческого издания массовой коммуникации. Последние же годы термин «инфографика» используется как средство популяризации, а графические средства не для передачи информации, а для украшения. 
В результате рассмотрения данной темы можно сделать вывод, что инфографика представляет собой новый метод художественной визуализации информации, где функция изображения меняется, а зрительный образ становится комплексным.

Таким образом, следует говорить об Инфографике, выступающей визуальной формой коммуникации, как о феномене формирования нового культурного языка и визуального кода визуальности современности посредством сосредоточения художественно-эстетических свойств со структурированным объемным пластом информации.

Рост популярности инфографики заставляет нас обратить на нее внимание с точки зрения преподавания иностранных языков.

Визуальная подача информации усваивается быстрее, чем при чтении обычного текста, ввиду ее четкой организации, небольшого объема, визуализации деталей и привлекательности подачи.

Без сомнения, инфографика может быть эффективно использована и на уроках иностранного языка.

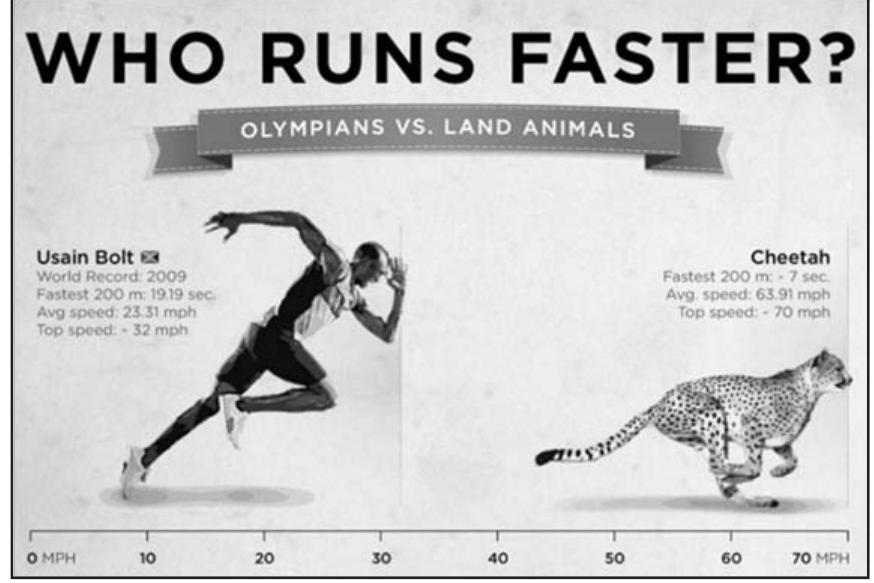

Рис. 1. Визуальная подача информации

Выделяют следующие преимущества использования элементов этой технологии на уроках:

- большее количество информации;

- богатый лексический материал, активный вокабуляр;

- решение большого количества задач;

- развитие визуальной грамотности учащихся;

- обучение детей критичному отношению к источникам информации.

Такие сервисы, как

1. http://www.visual.ly

2. www.dailyinfographic.com

\section{3. www.coolinfographics.com}

специализируются на создании и распространении инфографики, поэтому поиск материала не является затруднительным. Вокруг подходящего материала нужно построить занятие. Следующие задания подойдут для большей части инфографики:

- Найти в инфографике 5-10 интересных фактов.

- Проверить некоторые из них на истинность (найти подтверждение им в иных источниках).

- Сделать краткий устный отчет, используя инфографику.

- Составить тест по приведенной информации для проверки понимания другими учащимися.

- Ответить на вопрос: «Что именно удивило вас большего всего в данной инфографике?»

Использование инфографики не ограничивается только работой с навыками восприятия: существует достаточное количество инструментов для создания собственных.

Ресурсы

1. http://www.infogram.com

2. http://www.piktochart.com

3. http://www.canva.com

являются простыми онлайн-редакторами для построения инфографики.

Исходя из своего опыта, считаем приемлемым использовать следующие задания, связанные с подготовкой инфографики:

- Создание инфографики. основанной на тексте, который они только что прочитали, его главной идее.

- Перевод статистических данных из какого-либо текста в формат инфографики. Это применимо к какому-либо опросу в классе или к информации из делового журнала.

- Составление семантических карт, посвященных определенной тематике с добавлением инфографики.

- В грамматическом аспекте создание инфографики о временах глагола или с фразовыми глаголами.

Использование инфографики реализует такие образовательные задачи, как сбор информации, осмысление, выделение важного и второстепенного, переработка и перевод ее из одного вида в другой, что соответствует требованиям ФГОС.

Говоря о перспективах развития инфографики в образовательном процессе, в первую очередь хочется отметить, что письменная речь является сложным, многогранным видом речевой деятельности, так как учащемуся необходимо наиболее полно последовательно и понятно изложить сведения, факты, передать со- 
держание текста.

В 10-11 классах обучение иностранному языку должно способствовать развитию иноязычной коммуникативной компетенции, обеспечивающей использование иностранного языка в ситуациях официального и неофициального общения, а также в учебной, социальнобытовой, культурной сферах коммуникативного взаимодействия.

В соответствии с тем, что ведущим видом деятельности старшеклассников является учебно-профессиональная деятельность, обучение иностранному языку на этой ступени должно быть профессионально-ориентированным на формирование конкретных коммуникативных умений, например, реферировать, аннотировать, комментировать, переводить иностранный текст в различных условиях устного и письменного общения.

Следует отметить, что процесс обучения письменной речи имеет расхождения между графическим и смысловым способами выражения мысли. То есть в процессе составления высказывания ученики имеют проблемы с орфографической частью, так как их внимание переключается на смысловую сторону высказывания. Для качественного обучения письму на иностранном языке необходимо научить учащихся владеть всеми формами коммуникативной письменной речи, такими как: учебный конспект, тезисы, изложение, реферирование.

Также отведение важной роли обучения письменной речи позволяет реально использовать знание иностранного языка, находясь вне языковой среды, общаясь с носителями языка при помощи современных средств коммуникации: internet, e-mail, sms и др.

Как считает Н. Ю. Вторушина, в последние годы письмо начинают рассматривать как резерв в повышении эффективности обучения иностранному языку [4, с. 131].

Развитие и распространение социальных сетей оказывают влияние на способы восприятие информации молодежью. Особой популярностью пользуются краткие высказывания, оформленные в виде плакатов или картинок. Они обладают видимыми преимуществами, такими как: наглядность, краткость высказывания, емкость высказывания, набор ярких цветов, минимум текста.

Называют три основных вида инфографики по типу источника:

- аналитическая инфографика - в качестве источника информации используют аналитические материалы;

- новостная инфографика - в качестве источника информации используется новость;

- инфографика реконструкции - в основе данного типа используется определенное событие и воссоздается динамика событий в хронологическом порядке.

Широта применения позволяет использовать ее практически на любом языковом аспекте и на разных уровнях изучения языка.

Мы используем инфографику в рамках таких аспектов как «Устная практика», «Аналитическое чтение», «Деловой английский», где тексты изобилуют цифровыми данными, статистическими данными, сравнительным анализом.

Наилучшим для восприятия и воспроизведения изучаемого материала становятся такие обобщающие таблицы, где представлена проанализированная информация, например аналитическая инфографика.

В зависимости от уровня изучения языка, инфографика готовится к занятию как самим преподавателем, так и студентами. Чем выше уровень изучения языка, тем больше возможностей для составления данных инфографик самими студентами.

Мы рассматриваем также некоторые дополнительные возможности в развитии этой темы:

- найти в инфографике новую информацию;

- проанализировать представленную информацию и найти подтверждение ей или опровержение;

- по представленной схеме составить устное высказывание;

- расширить предложенную сжатую информацию до размера эссе и представить в письменной форме;

- дополнить инфографику недостающей информацией из текстов;

- составить инфографику самостоятельно (для студентов) по грамматическому материалу.

Позвольте обучающимся сделать свою собственную инфографику. Пусть сами решат, какой символ, фотография или надпись лучше соответствует тому, как они видят ту или иную информацию. Когда ученики вовлекаются в процесс создания инфографики, происходит «включение» (и развитие) их способностей к визуальному мышлению, обработке информации и использованию информационно-технических средств. В таком ракурсе изучение языка становится не самой целью, а инструментом, позволяющим развивать критическое мышление учеников и студентов, творческий подход, работу в команде. 


\section{ЛИТЕРАТУРА}

1. Веласко С. Еще раз о слове «инфографика» - [Электронный ресурс] - Режим доступа: http://infographer.ru/samuel-velasko-eshhe-raz-0-slove-infografika.

2. Вербицкий А.А. Активное обучение в высшей школе: контекстный подход / А.А. Вербицкий. - М.: Высш. шк., 1991. - С. 126.

3. Данилкина И.И. Визуальное воображение в трансформации культурной среды - [Электронный ресурс] - Режим доступа: http://analiculturolog.ru.

4. Тарасенко П.Н. Использование инфографики на сайтах испанских интернет-СМИ//Журналист. Социальные коммуникации. - 2011. - №2. - С.235.

5. Newsom D. and Haynes J. Public RelationWriting: Form and Style [Text]. - Cengage Learning, 2010. - 506 p

( Я яушева Нина Игнатьевна (n.i.yakusheva@yandex.ru), Молодчикова Галина Ивановна (galinamol2012@yandex.ru).

Журнал «Современная наука: актуальные проблемы теории и практики»

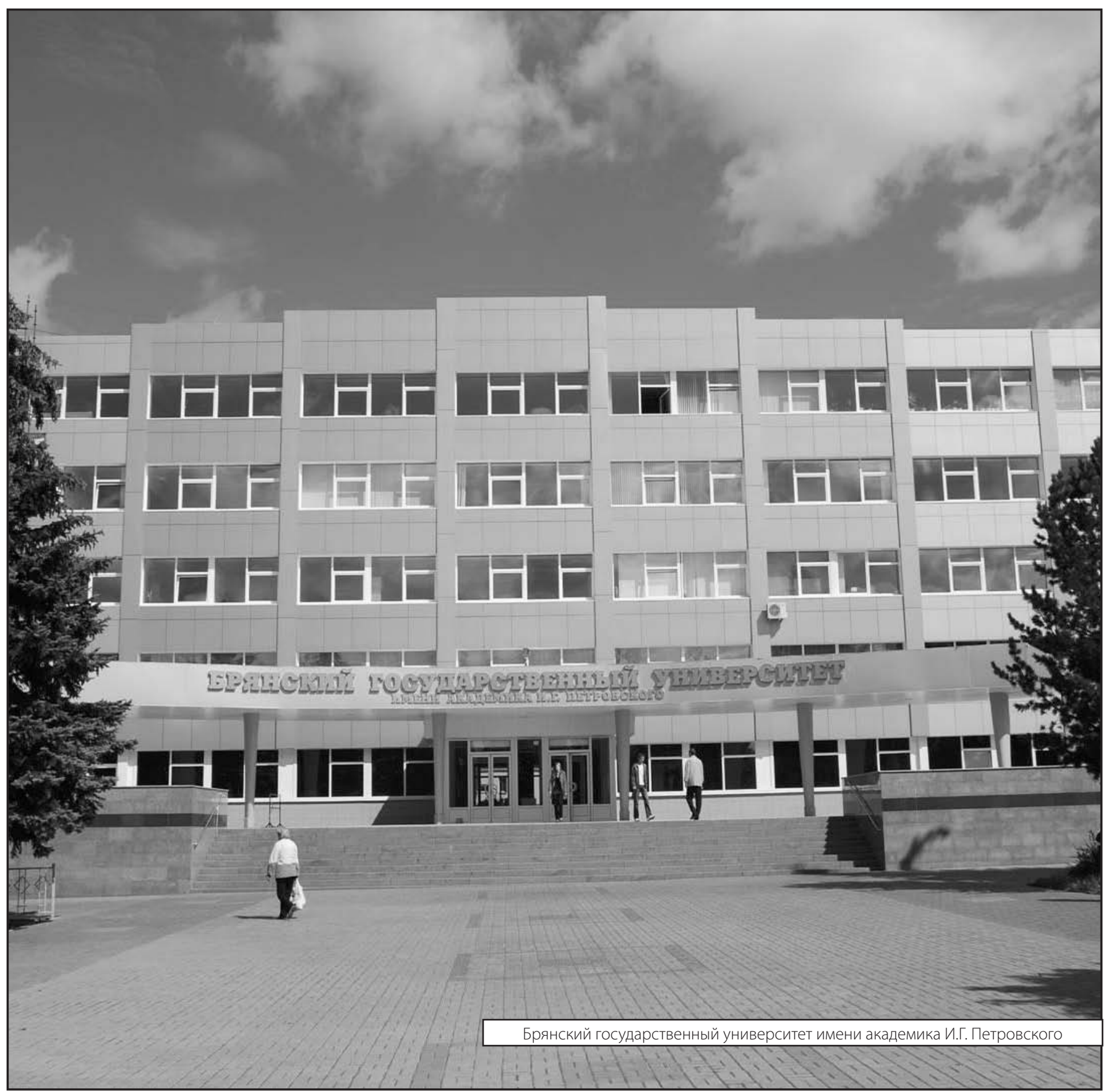

